\title{
Suckling Dome and the Australian-Woodlark plate boundary in eastern Papua: The geology of the Keveri and Ada'u Valleys
}

\section{D. LINDLEY}

PO Box 587, Yass, NSW 2582, Australia

Email address: david.lindley3@bigpond.com

\section{SUPPLEMENTARY PAPERS}

\author{
Australian Journal of Earth Sciences (2014) 61, 1125-1147. \\ http://dx.doi.org/10.1080/08120099.2014.965980
}

Copies of Supplementary Papers may be obtained from the Geological Society of Australia's website (www.gsa.org.au), the Australian Journal of Earth Scienecs website (www.ajes.com.au) or from the National Library of Australia's Pandora archive (http://nla.gov.au/nla.arc-25194).

\section{SUPPLEMENTARY PAPER}

Figure A1 Geological map of the Keveri and Ada'u Valleys, eastern Papua. (Figure 4a in published paper) 


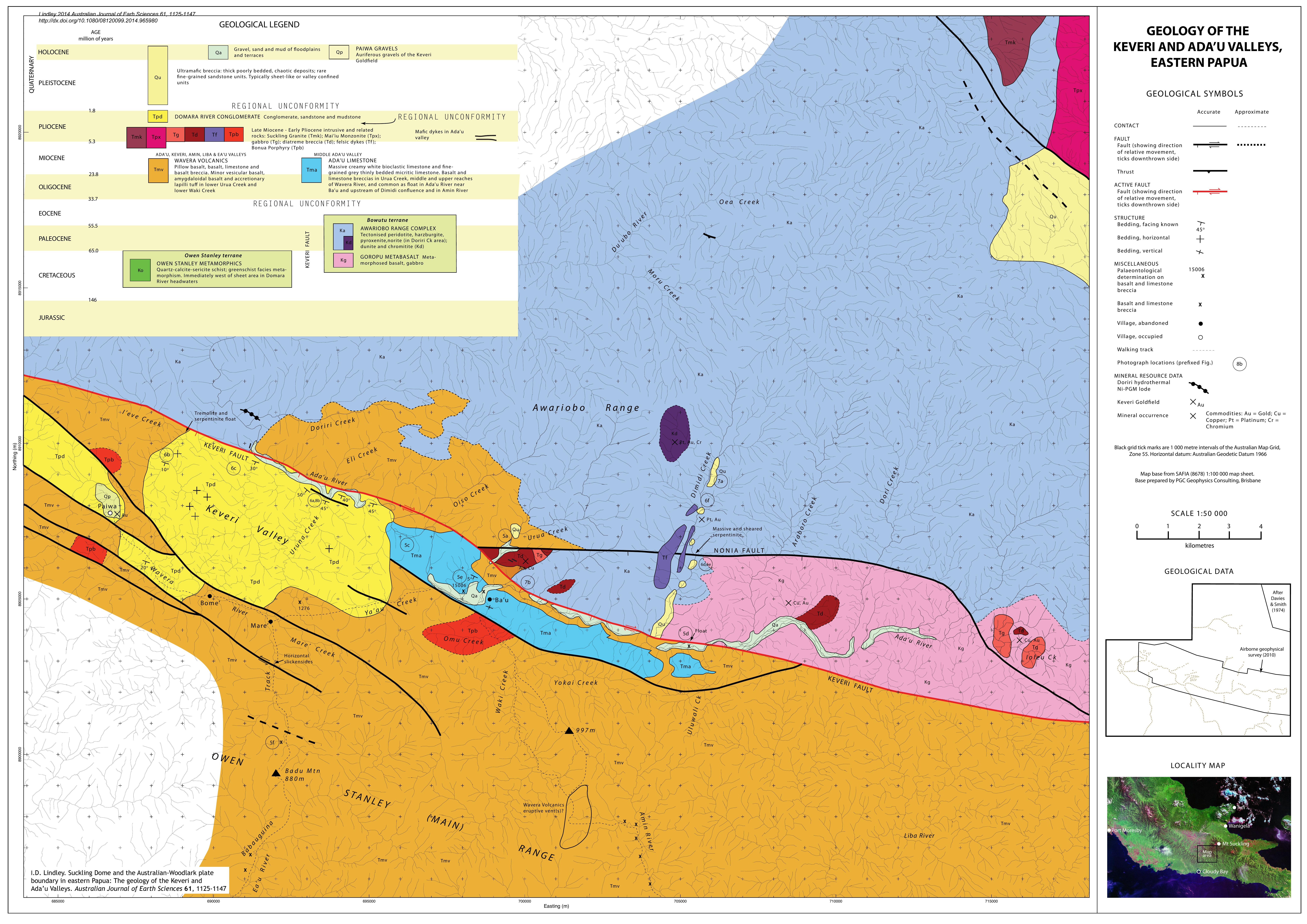

